\title{
Modelling the Efficiency of the Use of Production and Investment Resources at the Regional Level: The Case of Russia
}

Submitted 13/04/19, $1^{\text {st }}$ revision 19/05/19, $2^{\text {nd }}$ revision 20/06/19, Accepted 24/07/2019

\author{
Gayane L. Beklaryan ${ }^{1}$, Andranik S. Akopov ${ }^{2}$
}

\begin{abstract}
:
Purpose: The aim of this article is to examine the efficiency of the use of production and investment resources at the regional level in the Russian Federation.

Design/Methodology/Approach: The important feature of the suggested approach is to take into account the average (normative) return of sectoral resources by computing the efficiency scores of regions. Methods of agent-based modelling (ABM) were applied in the investigation using the 'gravity effects' that described the behaviour of agent-enterprises. Moreover, agent-investors regarding agent-regions are considered.

Findings: The key findings are: (1) There is a significant inequality and a gap between the leading regions of Russia (such as Moscow, Moscow Oblast and Saint Petersburg) and other regions. At the same time, many non-leading regions are more stable and attractive; (2) A complex classification of Russian regions based on solving four tasks, namely the 'ratio of production to labour', 'ratio of production to assets', 'ratio of investments to labour' and 'ratio of investments to assets' is an effective approach to estimate region states; (3) In the leading regions e.g., Moscow, has decreasing efficiency scores after 2014, which is probably due to the large influence of crisis phenomena on the largest Russian agglomerations in comparison with other regions; (4) The 'gravity model' explains the behaviour of economic agents and allows forecasting the number of regional enterprises and investors.

Practical implications: The developed method can be practically applied for other countries with non-homogeneous regional economies.

Originality/Value: For the first time the dynamical model of the efficiency of the use of production and investment resources at the regional level of Russia is suggested. Such model allows examining regional changes.
\end{abstract}

Keywords: Production and investment policy, regional economics, agent-based modelling.

JEL Classification: C63, E20, R11, R58.

Paper type. Research article.

\footnotetext{
${ }^{1}$ Plekhanov Russian University of Economics, glbeklaryan@gmail.com

${ }^{2}$ Plekhanov Russian University of Economics, andranik.s.akopov@ieee.org
} 


\section{Introduction}

As is well known, the regions of Russia are characterized by a high level of heterogeneity in terms of their production and investment characteristics. Such differentiation is caused by many factors, many of which are resource characteristics, in particular, fixed assets and labour resources by branches of the economy including industry, agriculture, transport and communication, etc. All Russian regions have their own specificity that is caused by the geography, climate, history, etc. At the present time, there are 85 administrative areas in the Russian Federation, including republics, territories, autonomous areas, federal cities (e.g. Moscow and Saint Petersburg) and other regions.

There is a line of research related to the analysis of the economic state of the Russian regions (Akopov and Beklaryan, 2014; Zinovyeva et al., 2016; Veselovsky et al., 2017; Berezhnaya et. al., 2018; Miloradov et al., 2018; Voronkova et al., 2018; Zelinskaya et al., 2018). This research is mostly devoted to some aspects of regional economics based on statistical data. For example, the regional CGE (Common General Equilibrium Model) is discussed in a study by Akopov and Beklaryan (2014) that aimed to identify the best forms of economic policy at the regional level. This model uses system dynamics methods developed by Forrester for the first time in the middle of the 20th century (Forrester, 1958). At the present time, system dynamics methods are supported in different simulation tools such as Powersim Studio, AnyLogic, iThink, etc. These methods and tools allow the development of simulation models of regional economic systems and decision-making systems for economic planning (Beklaryan, 2018). Modern computing systems such as AnyLogic (Borshchev, 2013) support multi-method simulation modelling based on both system dynamics (SD) and agent-based modelling (ABM) developed in the 1970s (Schelling, 1971) applying them jointly within one model. This approach has many advantages for the investigation of regional economic systems because such systems are decentralized with multiple internal nonlinear relations.

The purpose of this article is to examine production and investment characteristics at the regional level using the Russian Federation as a case study with the help of a developed simulation model. This model uses ABM methods, as well as the 'gravity effect' which explains the attraction of different agents to each other, e.g. agententerprises (companies) and agent-investors (organizations and individuals doing investments) to an agent-region. The attraction power for agents is directly proportional to the efficiency scores of production and investment resources used. In the results, the numbers of agents (companies and investors) forming at appropriate agent-regions can be forecast.

\section{Literature Review}

The research methodology is based on previous methods of system dynamics and agent-based modelling developed for regional systems (Akopov and Beklaryan, 
2014; Akopov et al., 2017). At the present time, ABM methods are applied for the research of regional economies (Berger, 2001; Baindur and Viegas, 2011). The importance of such methods has been described in many well-known works (Tesfatsion, 2002; Parker, 2003; Farmer and Foley, 2009; Epstein, 2012). Moreover, ABM is applicable for developing distributed optimisation methods (Akopov and Hevencev, 2013), environmental modelling (Akopov et al., 2019) and designing decision-making systems (Beklaryan, 2018).

There are several well-known studies in the field of modelling regional performance characteristics (Storper, 1997; Porter, 2003; Scott and Storper, 2003). Most aim to model different performance indicators of regions for their comprehensive analysis. An exception is the class of regional computable general equilibrium models (Partridge and Rickman, 1998) in which the dynamical interaction between different economic agents is considered. Nevertheless, the influence of regional production and investment characteristics on the dynamics of enterprises and investors is still poorly understood. Therefore, there is a need to extend methods of regional modelling to include mechanisms of agent behaviour such as the 'gravity effect'. For the first time, such an effect was described in works by Tinbergen (1962) and Anderson (1979) and was used for the investigation of bilateral trade processes. In subsequent years, this method was applied to examine the migration flows between different countries. However, never before has this approach been applied to study the formation of new agents (companies and investors) in regions taking into account their production and investment characteristics. The concept of the regional 'gravity effect' is illustrated in Figure 1.

Figure 1: The concept of the regional 'gravity effect'

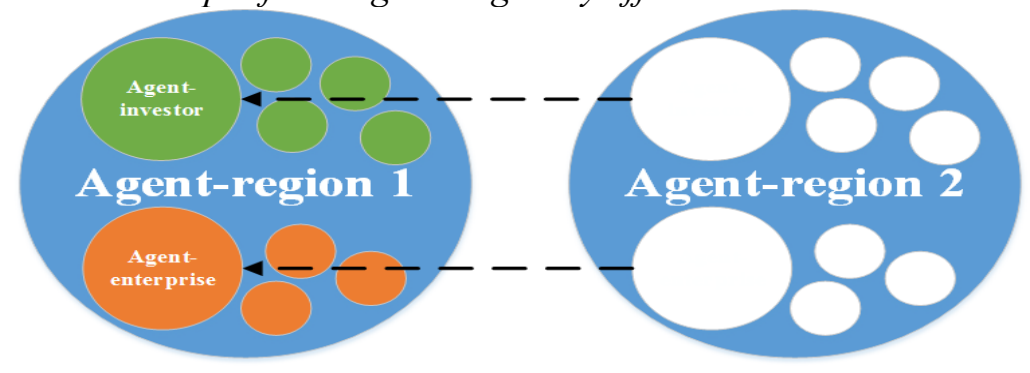

\section{Research Methodology}

In this model, agent-enterprises and agent-investors close in weak regions and appear in regions that are more attractive economically (Figure 1). In this work, the object of analysis is those Russian regions that possess fixed assets and labour resources. Such regions are characterized by their own economic activity whose results are the output and investments in fixed assets. The economic activity of a region is considered for five main branches of the economy:

- industry (including mining, manufacturing, production and distribution of electricity, gas and water); 
- agriculture (including hunting, forestry and fishing);

- construction;

- trade (including wholesale and retail trade; repair of motor vehicles, motorcycles, household goods and personal items);

- transport and communications.

At the same time, the following tasks are considered within the suggested model:

- 'Ratio of production to labour': the efficiency of using labour resources for the output is estimated;

- 'Ratio of production to assets': the efficiency of using fixed assets for the output is estimated;

- 'Ratio of investments to labour': the efficiency of using labour resources for attracting investments is estimated;

- 'Ratio of investments to assets': the efficiency of using fixed assets for attracting investments is estimated;

Further, the abstract description of the suggested model will be presented where:

- $\tilde{T}=\left\{t_{1}, t_{2}, \ldots, T\right\}$ is the set of time moments by years, $t \in \tilde{T}$ is the model time, $T$ is the ten-year period for the analysis of the regional economic efficiency;

- $\tilde{I}=\left\{i_{1}, i_{2}, \ldots, I\right\}$ is the set of indexes of agent-regions, $I$ is the number of agent-regions;

- $\tilde{J}=\left\{j_{1}, j_{2}, \ldots, J\right\}$ is the set of indexes of branches of the economy, $J$ is the number of branches of the economy;

- $\left\{K_{i j}(t), L_{i j}(t)\right\}$ are the fixed assets and labour resources of the $j^{\text {th }}$ branch of the economy $\left(j_{i} \in \tilde{J}\right)$ in the $i^{\text {th }}$ region $(i \in \tilde{I})$ at moment $t(t \in \tilde{T})$;

- $\left\{\tilde{K}_{i}(t), \tilde{L}_{i}(t)\right\}$ are summarized values (by all branches) of fixed assets and labour resources in the $i^{\text {th }}$ region $(i \in \tilde{I})$ at moment $t(t \in \tilde{T})$;

- $\quad\left\{\hat{K}_{j}(t), \hat{L}_{j}(t)\right\}$ are summarized values (by all regions) of fixed assets and labour resources of the $j^{\text {th }}$-branch of the economy $(j \in \tilde{J})$ at moment $t \quad(t \in \tilde{T})$;

- $\{\widehat{K}(t), \widehat{L}(t)\}$ are summarized values (by all regions and branches of the economy) fixed assets and labour resources at moment $t$ $(t \in \tilde{T})$; 
- $\left\{V_{i j}(t), \operatorname{In}_{i j}(t)\right\}$ are volumes of output and investments of the $j^{\text {th }}$ branch of the economy $(j \in \tilde{J})$ in the $i^{\text {th }}$ - region $(i \in \tilde{I})$ at moment $t(t \in \tilde{T})$;

- $\left\{\tilde{V}_{i}(t), \operatorname{In}_{i}(t)\right\}$ are summarized volumes (by all branches) of outputs and investments in the $i^{\text {th }}$-region $(i \in \tilde{I})$ at moment $t \quad(t \in \tilde{T})$;

- $\left\{V_{j}(t), I n_{j}(t)\right\}$ are summarized volumes (by all regions) of outputs and investments of the $j^{\text {th }}$-branch of the economy $(j \in \tilde{J})$ at moment $t \quad(t \in \tilde{T})$;

- $\quad\{\hat{V}(t), \operatorname{In}(t)\}$ are summarized volumes (by all regions and branches) of outputs and investments at moment $t(t \in \tilde{T})$;

- $\left\{U_{i j 1}(t), U_{i j 2}(t), U_{i j 3}(t), U_{i j 4}(t)\right\}$ are efficiency scores of $j^{\text {ths }}$ branches of the economy $(j \in \tilde{J})$ of $i^{\text {th }}$-regions $(i \in \tilde{I})$ in tasks of the 'Ratio of production to labour', 'Ratio of investments to labour', 'Ratio of production to assets' and 'Ratio of investments to assets' at moment $t \quad(t \in \tilde{T})$;

- $\quad\left\{\tilde{U}_{i 1}(t), \tilde{U}_{i 2}(t), \tilde{U}_{i 3}(t), \tilde{U}_{i 4}(t)\right\}$ are the total (for all branches) efficiency scores of $i^{t h s}$ - regions $(i \in \tilde{I})$ at moment $t(t \in \tilde{T})$.

At the same time, the following balance relations are performed for the resource characteristics of the model at each time $t(t \in \tilde{T})$ :

$$
\begin{aligned}
& \tilde{K}_{i}(t)=\sum_{j=1}^{J} K_{i j}(t), \tilde{L}_{i}(t)=\sum_{j=1}^{J} L_{i j}(t), \\
& \hat{K}_{j}(t)=\sum_{i=1}^{I} K_{i j}(t), \hat{L}_{j}(t)=\sum_{i=1}^{I} L_{i j}(t), \\
& \hat{K}(t)=\sum_{i=1}^{I} \tilde{K}_{i}(t)=\sum_{j=1}^{J} \hat{K}_{j}(t), \hat{L}(t)=\sum_{i=1}^{I} \tilde{L}_{i}(t)=\sum_{j=1}^{J} \hat{L}_{j}(t) .
\end{aligned}
$$

Similar balance relations are performed for the resulting characteristics of the model at each time $t \quad(t \in \tilde{T})$ :

$$
\begin{aligned}
& \tilde{V}_{i}(t)=\sum_{j=1}^{J} V_{i j}(t), \operatorname{In}_{i}(t)=\sum_{j=1}^{J} \operatorname{In}_{i j}(t), \\
& \hat{V}_{j}(t)=\sum_{i=1}^{I} V_{i j}(t), \quad \operatorname{In}(t)=\sum_{i=1}^{I} \operatorname{In}_{i j}(t),
\end{aligned}
$$




$$
\widehat{V}(t)=\sum_{i=1}^{I} \tilde{V}_{i}(t)=\sum_{j=1}^{J} \hat{V}_{j}(t), \operatorname{In}(t)=\sum_{i=1}^{I} \operatorname{In}_{i}(t)=\sum_{j=1}^{J} \operatorname{In}_{j}(t) .
$$

The total efficiency scores of the $i^{t h}$-region $(i \in \tilde{I})$ at moment $t(t \in \tilde{T})$ :

$$
\begin{gathered}
U_{i 1}(t)=\frac{1}{\tilde{L}_{i}} \sum_{j=1}^{J} \frac{V_{i j}(t)}{W_{j 1}(t)}, U_{i 2}(t)=\frac{1}{\tilde{K}_{i}} \sum_{j=1}^{J} \frac{V_{i j}(t)}{W_{j 2}(t)}, \\
U_{i 3}(t)=\frac{1}{\tilde{L}_{i}} \sum_{j=1}^{J} \frac{I n_{i j}(t)}{W_{j 3}(t)}, U_{i 4}(t)=\frac{1}{\tilde{K}_{i}} \sum_{j=1}^{J} \frac{I n_{i j}(t)}{W_{j 4}(t)}, \\
\text { subject to the following conditions: } \\
\sum_{i=1}^{I} U_{i 1}(t) K_{i}(t)=\hat{K}(t), \sum_{i=1}^{I} U_{i 2}(t) L_{i}(t)=\widehat{L}(t) .
\end{gathered}
$$

At the same time, the average (normative) return of sectoral resources of the $j^{\text {th }}$ branch of the economy $(j \in \tilde{J})$ at moment $t(t \in \tilde{T})$ :

$$
\begin{aligned}
& W_{j 1}(t)=\frac{\hat{V}_{j}(t)}{\sum_{i=1}^{I} L_{i j}(t) U_{i 1}(t)}, W_{j 2}(t)=\frac{\hat{V}_{j}(t)}{\sum_{i=1}^{I} K_{i j}(t) U_{i 2}(t)}, \\
& W_{j 3}(t)=\frac{I n_{j}(t)}{\sum_{i=1}^{I} L_{i j}(t) U_{i 3}(t)}, W_{j 4}(t)=\frac{I n_{j}(t)}{\sum_{i=1}^{I} K_{i j}(t) U_{i 4}(t)} .
\end{aligned}
$$

The state of the $i^{\text {th }}$-region $(i \in \tilde{I})$ that characterizes the efficiency of using sectoral resources for the production and investment activity at moment $t(t \in \tilde{T})$ is defined by the following rules:

$$
s t_{i}(t)=\left\{\begin{array}{l}
1, \text { if I is true, } \\
2, \text { if II is true, } \\
3, \text { if III is true, }
\end{array}\right.
$$

I. $\quad U_{i 1}(\mathrm{t})>\underline{U}_{i 1}$ и $U_{i 2}(\mathrm{t})>\underline{U}_{i 2}$ и $U_{i 3}(\mathrm{t})>\underline{U}_{i 3}$ и $U_{i 4}(\mathrm{t})>\underline{U}_{i 4}$, or $\underline{U}_{i 3} \leq U_{i 3}(\mathrm{t}) \leq \underline{U}_{i 3}$ or $\underline{\underline{U}}_{i 4} \leq U_{i 4}(\mathrm{t}) \leq \underline{U}_{i 4}$,

II. $\underline{U}_{i 1} \leq U_{i 1}(\mathrm{t}) \leq \underline{U}_{i 1}$ or $\underline{U}_{i 2} \leq U_{i 2}(\mathrm{t}) \leq \underline{U}_{i 2}$,

III. $U_{i 1}(\mathrm{t})<\underline{\underline{U}}_{i 1}$ or $U_{i 2}(\mathrm{t})<\underline{\underline{U}}_{i 2}$ or $U_{i 3}(\mathrm{t})<\underline{\underline{U}}_{i 3}$ or $U_{i 4}(\mathrm{t})<\underline{\underline{U}}_{i 4}$.

Also:

- $\quad s t_{i}(t) \in\{1,2,3\}$ is the set of states of the $i^{\text {th }}$-region $(i \in \tilde{I})$ that characterize the efficiency of using fixed assets and labour resources for production and 
investment activities respectively: $s t_{i}(t)=1$ is a positive sate, $s t_{i}(t)=2$ is a satisfactory state, and $s t_{i}(t)=3$ is a negative state;

- $\left\{\underline{U}_{i 1}, \underline{U}_{i 2}, \underline{U}_{i 3}, \underline{U}_{i 4}\right\}$ are threshold values of efficiency scores needed for including the $i^{\text {th }}$-region to the cluster of regions with positive states (exogenous parameters);

- $\left\{\underline{\underline{U}}_{i 1}, \underline{\underline{U}}_{i 2}, \underline{\underline{U}}_{i 3}, \underline{\underline{U}}_{i 4}\right\}$ are threshold values of efficiency scores needed for including the $i^{\text {th }}$-region to the cluster of regions with satisfactory states (exogenous parameters).

The forecast values of the total numbers of agent-enterprises (companies) and agentinvestors (organization doing investments) in the $i^{\text {th }}$-region $(i \in \tilde{I})$ at moment $t$ $(t \in \tilde{T})$ are:

$$
\begin{gathered}
N_{i 1}(t)=\left\{\begin{array}{l}
N_{i 1}(t-1)+\sigma_{1} U_{i 1}\left(t-\tau_{1}\right)+\sigma_{2} U_{i 2}\left(t-\tau_{2}\right), \text { if } \mathrm{st}_{i}(\mathrm{t})=1, \\
N_{i 1}(t-1), \text { if } \mathrm{st}_{i}(t)=2, \\
N_{i 1}(t-1)-\sigma_{1} U_{i 1}\left(t-\tau_{1}\right)+\sigma_{2} U_{i 2}\left(t-\tau_{2}\right), \text { if } \mathrm{st}_{i}(t)=3,
\end{array}\right. \\
N_{i 2}(t)=\left\{\begin{array}{l}
N_{i 2}(t-1)+\sigma_{3} U_{i 1}\left(t-\tau_{1}\right)+\sigma_{4} U_{i 2}\left(t-\tau_{2}\right), \text { if } \mathrm{st}_{i}(\mathrm{t})=1, \\
N_{i 2}(t-1), \text { if } \mathrm{st}_{i}(t)=2, \\
N_{i 2}(t-1)-\sigma_{3} U_{i 3}\left(t-\tau_{1}\right)+\sigma_{4} U_{i 4}\left(t-\tau_{2}\right), \text { if } \mathrm{st}_{i}(t)=3,
\end{array}\right.
\end{gathered}
$$

where

$N_{1}(t)$ is the total number of agent-enterprises;

$N_{2}(t)$ is the total number of agent-investors;

$\left\{\sigma_{1}, \sigma_{2}, \sigma_{3}, \sigma_{4}\right\}$ are regression coefficients;

$\left\{\tau_{1}, \tau_{2}\right\}$ are time lags that are defined by the inertness in decision-making systems of agent-enterprises and agent-investors respectively (usually one year).

The model (1)-(14) is implemented in AnyLogic, which supports methods of agentbased modelling by allowing spatial data to be treated (Figure 2). The special iteration procedure allowing efficiency scores (7)-(8) to be completed was developed using Java, a core of AnyLogic.

\section{Results}

The model (1)-(14) was tested and validated using open empirical data provided by the Federal State Statistics Service of the Russian Federation ${ }^{3}$. The well-known method of least squares was used for the computation of the regression coefficients. At the same time, the special iteration procedure was developed and applied to compute the efficiency scores (7)-(8) by taking into account the average returns of sectoral resources (10)-(11). In Table 1, the regions are classified into three clusters

\footnotetext{
${ }^{3}$ http://www.gks.ru/wps/wcm/connect/rosstat_main/rosstat/en/main/
} 
depending on their efficiency scores for the first pair of tasks 'Ratio of production to labour' and 'Ratio of production to assets' in 2016.

Figure 2: The developed regional simulation model.

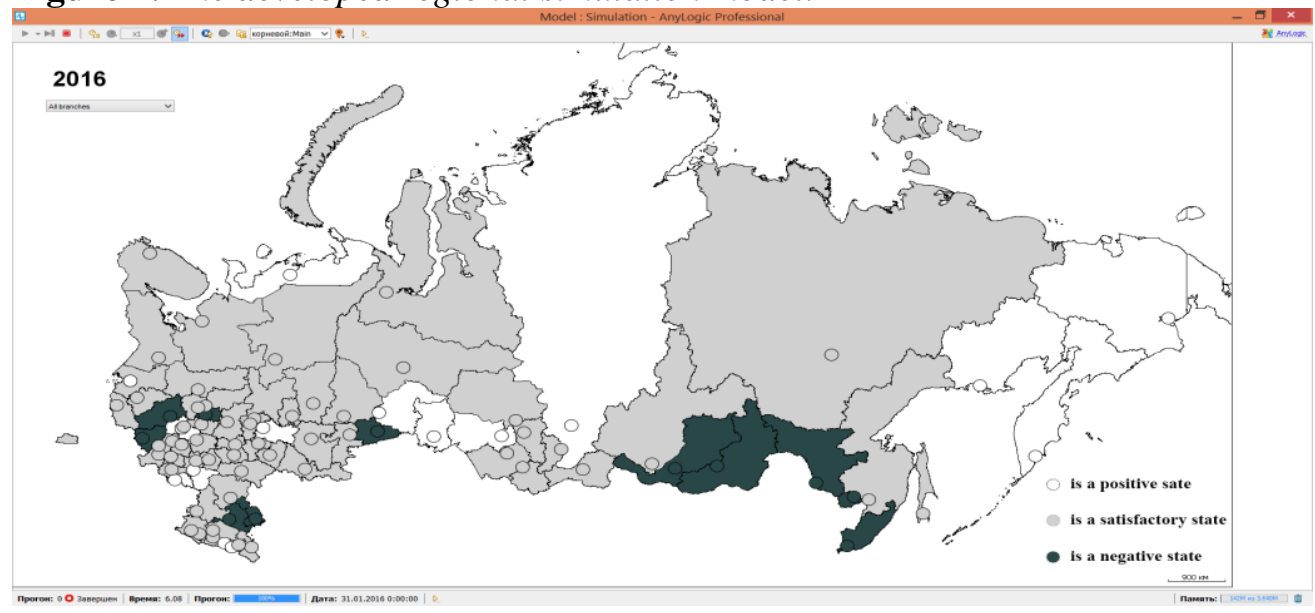

Table 1. Classification of Russian regions by the efficiency of using resources for production activity

\begin{tabular}{|c|c|c|}
\hline & \multicolumn{2}{|l|}{ The first pair of tasks } \\
\hline & Ratio of production to labour & Ratio of production to assets \\
\hline Higher & $\begin{array}{l}\text { Moscow, Magadan Oblast, } \\
\text { Nenets Autonomous Okrug, } \\
\text { Belgorod Oblast, Moscow } \\
\text { Oblast, Chukotka Autonomous } \\
\text { Okrug, Krasnoyarsk Krai, Saint- } \\
\text { Petersburg }\end{array}$ & $\begin{array}{l}\text { Moscow, Altai Krai, Omsk } \\
\text { Oblast, The Republic of } \\
\text { Adygea, Moscow Oblast, } \\
\text { Belgorod Oblast, Karachay- } \\
\text { Cherkess Republic, Kabardino- } \\
\text { Balkar Republic, Saint- } \\
\text { Petersburg, } \\
\text { The Republic of Ingushetia }\end{array}$ \\
\hline High & $\begin{array}{l}\text { Omsk Oblast, Kamchatka Krai, } \\
\text { Republic of North Ossetia - } \\
\text { Alania, Voronezh Oblast, } \\
\text { Novosibirsk Oblast, Kabardino- } \\
\text { Balkar Republic, The Republic } \\
\text { of Tatarstan, Tyumen Oblast, } \\
\text { Kaliningrad Oblast, The } \\
\text { Republic of Sakha (Yakutia), } \\
\text { Sakhalin Oblast, Altai Krai, } \\
\text { Khanty-Mansi Autonomous } \\
\text { Okrug - Yugra, The Republic of } \\
\text { Ingushetia }\end{array}$ & $\begin{array}{l}\text { Voronezh Oblast, Republic of } \\
\text { North Ossetia - Alania, } \\
\text { Novosibirsk Oblast, Tuva, } \\
\text { Kamchatka Krai, Krasnoyarsk } \\
\text { Krai, The Republic of } \\
\text { Dagestan, Kaliningrad Oblast, } \\
\text { Vladimir Oblast, The Republic } \\
\text { of Tatarstan, Magadan Oblast, } \\
\text { Rostov Oblast, Ulyanovsk } \\
\text { Oblast, Tula Oblast, Republic } \\
\text { of Bashkortostan }\end{array}$ \\
\hline Average & $\begin{array}{l}\text { Tula Oblast, Republic of } \\
\text { Bashkortostan, Rostov Oblast, } \\
\text { The Republic of Adygea, } \\
\text { Yamalo-Nenets Autonomous } \\
\text { Okrug, Vladimir Oblast, } \\
\text { Murmansk Oblast, Oryol Oblast, } \\
\text { Udmurtia, Ulyanovsk Oblast, }\end{array}$ & $\begin{array}{l}\text { Oryol Oblast, The Republic of } \\
\text { Altai, Chechen Republic, } \\
\text { Udmurtia, Bryansk Oblast, } \\
\text { Kursk Oblast, Chelyabinsk } \\
\text { Oblast, Tyumen Oblast, } \\
\text { Tambov Oblast, The Republic } \\
\text { of Mari El, Irkutsk Oblast, }\end{array}$ \\
\hline
\end{tabular}


Irkutsk Oblast, Tuva, The Republic of Dagestan, Kursk Oblast, Chelyabinsk Oblast, Tambov Oblast, The Republic of Komi, Tomsk Oblast, KarachayCherkess Republic, Samara Oblast, Khabarovsk Krai, Nizhny Novgorod Oblast, The Republic of Khakassia, Leningrad Oblast, Lipetsk Oblast, The Republic of Altai, Chechen Republic, Krasnodar Krai, Orenburg Oblast, Bryansk Oblast, Kaluga Oblast, The Republic of Mari El, Sverdlovsk Oblast, Novgorod Oblast, Perm Krai, Stavropol Krai, Penza Oblast, Vologda Oblast, Yaroslavl Oblast, Republic of Karelia, Arkhangelsk Oblast, Saratov Oblast, Kemerovo Oblast, Pskov Oblast, Kostroma Oblast, Kirov Oblast, Volgograd Oblast, The Republic of Mordovia, Chuvash Republic, Ryazan Oblast

Low
Primorsky Krai, Astrakhan Oblast, Amur Oblast, Ivanovo Oblast, Smolensk Oblast, The Republic of Buryatia, Zabaykalsky Krai, Tver Oblast, Kurgan Oblast, The Republic of Kalmykia, Jewish Autonomous Oblast
Stavropol Krai, Samara Oblast, Penza Oblast, The Republic of Khakassia, Nizhny Novgorod Oblast, Ivanovo Oblast, Krasnodar Krai, Pskov Oblast, Kaluga Oblast, Chuvash Republic, Kirov Oblast, Lipetsk Oblast, Tomsk Oblast, Yaroslavl Oblast, Khabarovsk Krai, Orenburg Oblast, The Republic of Mordovia, Novgorod Oblast, Kemerovo Oblast, Republic of Karelia, Saratov Oblast, Kostroma Oblast, Volgograd Oblast, Murmansk Oblast, Arkhangelsk Oblast, Chukotka Autonomous Okrug, Ryazan Oblast, Leningrad Oblast, Vologda Oblast, Perm Krai, Sverdlovsk Oblast, Smolensk Oblast, Primorsky Krai, Astrakhan Oblast, The Republic of Buryatia, Sakhalin Oblast

Sakhalin Oblast, Khanty-Mansi Autonomous Okrug - Yugra, The Republic of Sakha (Yakutia), Amur Oblast, Zabaykalsky Krai, Tver Oblast, The Republic of Kalmykia, Kurgan Oblast, Nenets Autonomous Okrug, Jewish Autonomous Oblast, The Republic of Komi, YamaloNenets Autonomous Okrug

In Table 2, the regions are classified into three clusters depending on their efficiency scores for the second pair of tasks 'Ratio of investments to labour' and 'Ratio of investments to assets' in 2016.

Table 2. Classification of Russian regions by the efficiency of using resources for investment activity

\begin{tabular}{l|l|l}
\hline & The second pair of tasks \\
\hline \multirow{3}{*}{ Higher } & Ratio of investments to labour & Ratio of investments to assets \\
\hline & Yamalo-Nenets Autonomous & Magadan Oblast, Voronezh \\
& Okrug, Magadan Oblast, Nenets & Oblast, Karachay-Cherkess \\
& Autonomous Okrug, The & Republic, Amur Oblast, \\
& Republic of Komi, Sakhalin & Novgorod Oblast, Tyumen \\
& Oblast, The Republic of Sakha & Oblast, Tuva, Krasnoyarsk Krai \\
& (Yakutia), Amur Oblast, & \\
& Tyumen Oblast, Voronezh & \\
\hline
\end{tabular}




\begin{tabular}{|c|c|c|}
\hline & $\begin{array}{l}\text { Oblast, Khanty-Mansi } \\
\text { Autonomous Okrug - Yugra, } \\
\text { Novgorod Oblast, Krasnoyarsk } \\
\text { Krai }\end{array}$ & \\
\hline High & $\begin{array}{l}\text { Chukotka Autonomous Okrug, } \\
\text { Leningrad Oblast, Kaliningrad } \\
\text { Oblast, Kamchatka Krai, Saint- } \\
\text { Petersburg, The Republic of } \\
\text { Tatarstan, Astrakhan Oblast, } \\
\text { Irkutsk Oblast, Kursk Oblast, } \\
\text { Republic of Bashkortostan, } \\
\text { Karachay-Cherkess Republic, } \\
\text { Tuva, Belgorod Oblast, Bryansk } \\
\text { Oblast, Murmansk Oblast, } \\
\text { Tomsk Oblast, Vologda Oblast, } \\
\text { Chechen Republic, Khabarovsk } \\
\text { Krai, Tambov Oblast, Kaluga } \\
\text { Oblast, Moscow }\end{array}$ & $\begin{array}{l}\text { Bryansk Oblast, Chechen } \\
\text { Republic, Kursk Oblast, } \\
\text { Republic of Bashkortostan, } \\
\text { Rostov Oblast, Irkutsk Oblast, } \\
\text { Sakhalin Oblast, Belgorod } \\
\text { Oblast, The Republic of } \\
\text { Adygea, Astrakhan Oblast, } \\
\text { Leningrad Oblast, Omsk } \\
\text { Oblast, Kaluga Oblast, Tambov } \\
\text { Oblast, Tula Oblast, The } \\
\text { Republic of Sakha (Yakutia), } \\
\text { Samara Oblast, Moscow, } \\
\text { Nenets Autonomous Okrug, } \\
\text { Tomsk Oblast, Khabarovsk } \\
\text { Krai, The Republic of } \\
\text { Ingushetia }\end{array}$ \\
\hline Average & $\begin{array}{l}\text { Rostov Oblast, Tula Oblast, } \\
\text { Samara Oblast, Perm Krai, } \\
\text { Krasnodar Krai, Zabaykalsky } \\
\text { Krai, Jewish Autonomous } \\
\text { Oblast, Orenburg Oblast, } \\
\text { Moscow Oblast, Volgograd } \\
\text { Oblast, Lipetsk Oblast, Omsk } \\
\text { Oblast, The Republic of Adygea, } \\
\text { Arkhangelsk Oblast, Tver } \\
\text { Oblast, Saratov Oblast, The } \\
\text { Republic of Mordovia, Yaroslavl } \\
\text { Oblast, Chelyabinsk Oblast, The } \\
\text { Republic of Altai, Republic of } \\
\text { North Ossetia - Alania, Kirov } \\
\text { Oblast, Vladimir Oblast, } \\
\text { Kemerovo Oblast, Nizhny } \\
\text { Novgorod Oblast, Stavropol } \\
\text { Krai }\end{array}$ & $\begin{array}{l}\text { Yamalo-Nenets Autonomous } \\
\text { Okrug, Krasnodar Krai, } \\
\text { Moscow Oblast, Altai Krai, } \\
\text { Khanty-Mansi Autonomous } \\
\text { Okrug - Yugra, The Republic } \\
\text { of Komi, Zabaykalsky Krai, } \\
\text { Vologda Oblast, Volgograd } \\
\text { Oblast, The Republic of Altai, } \\
\text { Orenburg Oblast, Lipetsk } \\
\text { Oblast, Murmansk Oblast, } \\
\text { Vladimir Oblast, The Republic } \\
\text { of Mordovia, Chukotka } \\
\text { Autonomous Okrug, Perm } \\
\text { Krai, Tver Oblast, Ulyanovsk } \\
\text { Oblast, Saratov Oblast, Kirov } \\
\text { Oblast, Republic of North } \\
\text { Ossetia - Alania, Yaroslavl } \\
\text { Oblast, Arkhangelsk Oblast, } \\
\text { Stavropol Krai, Chelyabinsk } \\
\text { Oblast, Kabardino-Balkar } \\
\text { Republic, Kemerovo Oblast, } \\
\text { Novosibirsk Oblast, Nizhny } \\
\text { Novgorod Oblast }\end{array}$ \\
\hline Low & $\begin{array}{l}\text { Oryol Oblast, Republic of } \\
\text { Karelia, Udmurtia, Ulyanovsk } \\
\text { Oblast, Novosibirsk Oblast, } \\
\text { Smolensk Oblast, Sverdlovsk } \\
\text { Oblast, Kabardino-Balkar } \\
\text { Republic, Pskov Oblast, Altai } \\
\text { Krai, Kostroma Oblast, The } \\
\text { Republic of Buryatia, Penza } \\
\text { Oblast, Ryazan Oblast, The } \\
\text { Republic of Mari El, The } \\
\text { Republic of Ingushetia, The } \\
\text { Republic of Khakassia, }\end{array}$ & $\begin{array}{l}\text { Oryol Oblast, Jewish } \\
\text { Autonomous Oblast, Udmurtia, } \\
\text { Pskov Oblast, Republic of } \\
\text { Karelia, Smolensk Oblast, } \\
\text { Penza Oblast, Kostroma } \\
\text { Oblast, The Republic of Mari } \\
\text { El, The Republic of Buryatia, } \\
\text { Ryazan Oblast, Chuvash } \\
\text { Republic, The Republic of } \\
\text { Khakassia, Sverdlovsk Oblast, } \\
\text { Primorsky Krai, Ivanovo } \\
\text { Oblast, Kurgan Oblast, The }\end{array}$ \\
\hline
\end{tabular}




Primorsky Krai, Chuvash
Republic, Kurgan Oblast, The
Republic of Kalmykia, Ivanovo
Oblast, The Republic of
Dagestan

Primorsky Krai, Chuvash

Republic, Kurgan Oblast, The

Oblast, The Republic of

Dagestan
Republic of Kalmykia, The

Republic of Dagestan

It should be highlighted that the leading regions (Moscow, Moscow Oblast, SaintPetersburg) that are included in the higher cluster on using resources for production activity (Table 1) are not related to the higher cluster on using resources for investment activity (Table 2). Moreover, this demonstrates the lower stability of the dynamics of the efficiency scores compared to some other Russian regions (Altai Krai, Irkutsk Oblast, the Republic of Tatarstan).

Figures 3 and 4 show estimations of the efficiency by using labour resources for some Russian regions having stable dynamics of growth from 2012 to 2016 within the first pair of tasks 'Ratio of production to labour' and 'Ratio of production to assets'.

Figure 3. The dynamics of the efficiency of using labour resources in the production activity of some Russian regions

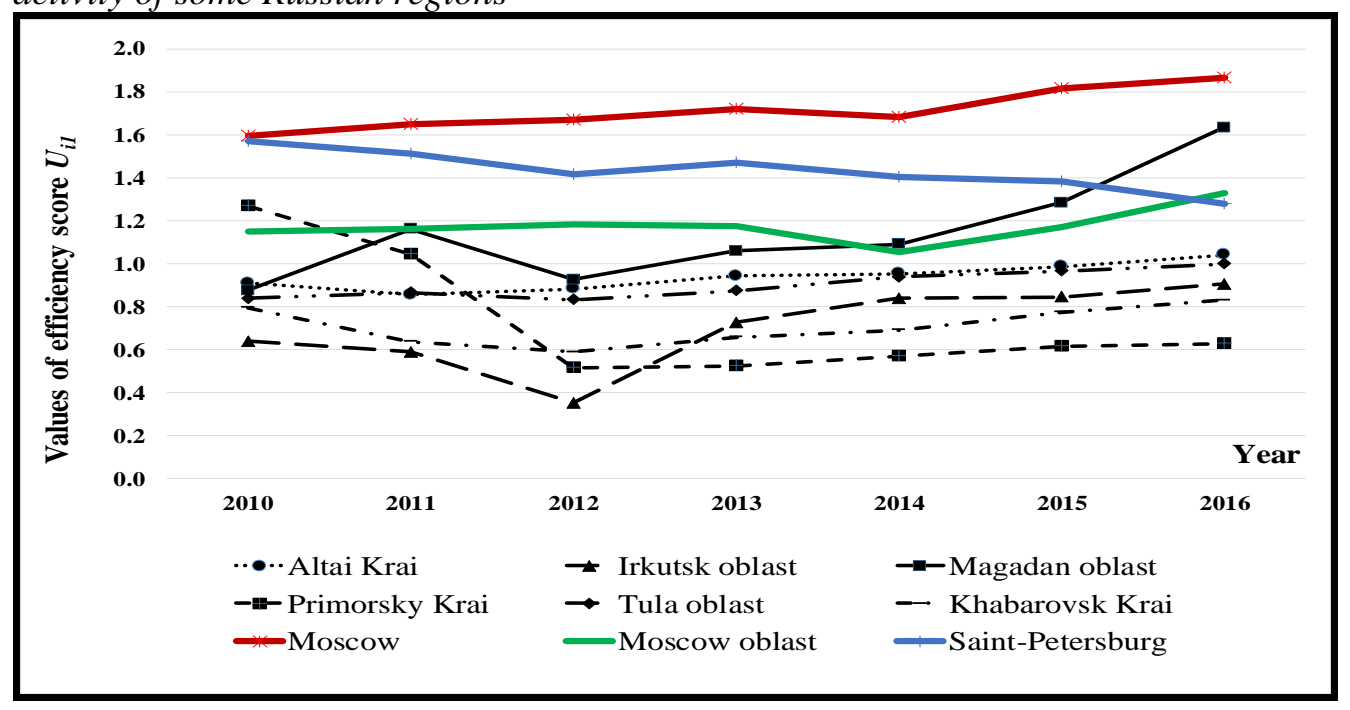

As shown in Figures 3 and 4, the majority of regions (Altai Krai, Irkutsk Oblast, the Republic of Tatarstan) that demonstrate a steady increase in the efficiency of using labour resources mainly belong to the cluster of regions with high efficiency (Table 1). In contrast, in central regions, in particular, Moscow, Moscow Oblast and St. Petersburg, decreasing efficiency scores are observed in 2014 compared to the previous year. This is probably due to the large impact of crisis phenomena on the largest Russian agglomerations in comparison with other regions of the Russian Federation. At the same time, a restoration in the positive dynamics in Moscow and Saint Petersburg is observed after 2014. 
Modelling the Efficiency of the Use of Production and Investment Resources at the Regional 162

Figure 4. The dynamics of the efficiency of using fixed assets in the production activity of some Russian regions

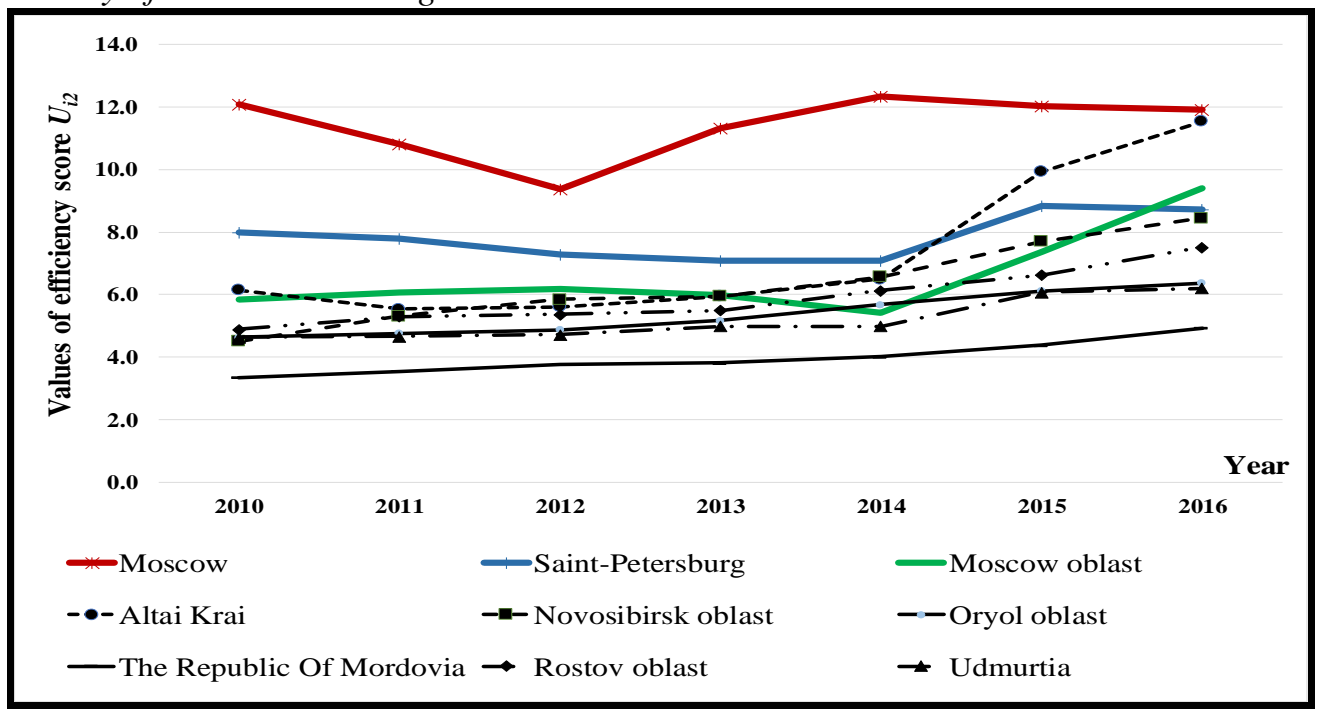

Figures 5 and 6 show estimations of the efficiency of using labour resources for some regions having stable dynamics of growth from 2012 to 2016 within the second pair of tasks 'Ratio of production to assets' and 'Ratio of investments to assets'.

Figure 5. The dynamics of the efficiency of using labour resources in the investment activity of some Russian regions

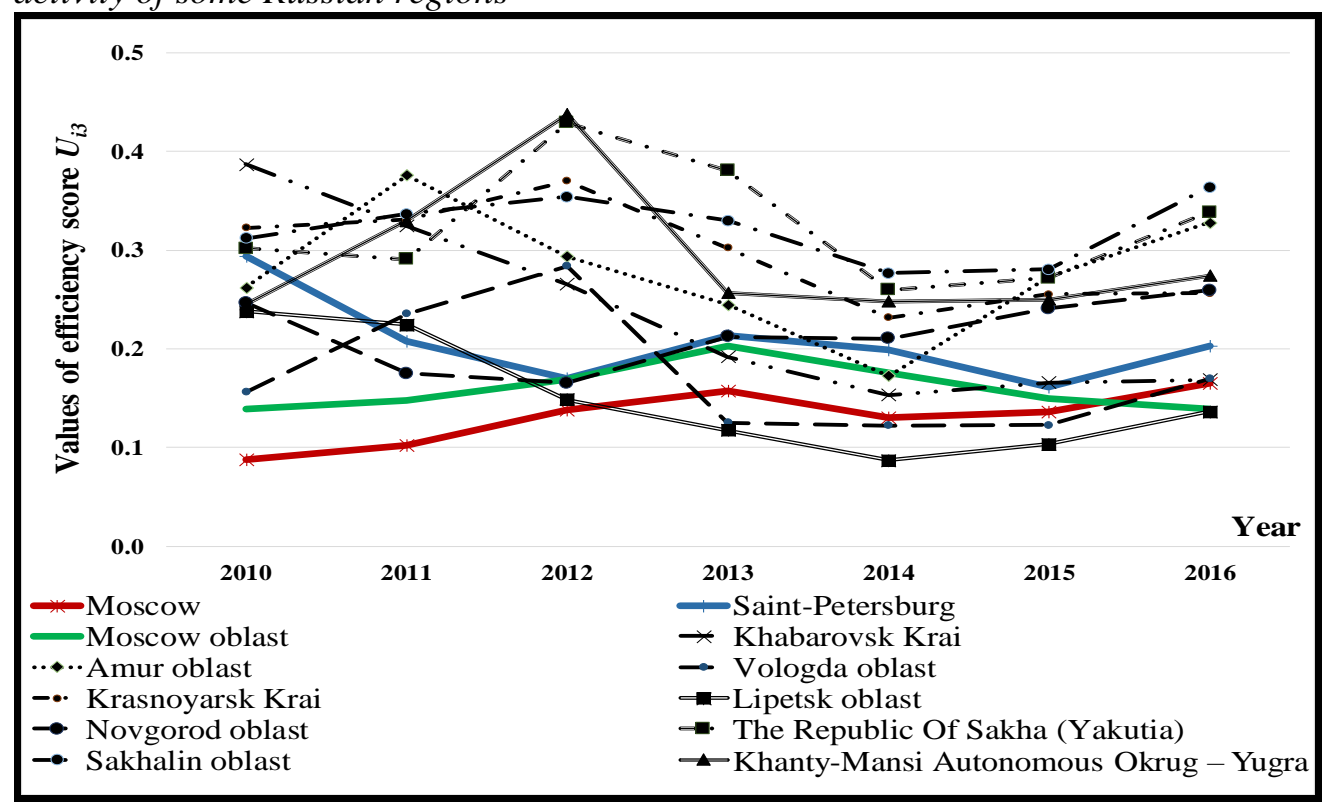


It should be highlighted that a fall was observed in the dynamics of the efficiency of using labour resources in the investment activity for the majority of Russian regions during the period 2010 - 2014, with an ensuing gradual recovery (Figure 5).

Figure 6. The dynamics of the efficiency of using fixed assets in the investment activity of some Russian regions

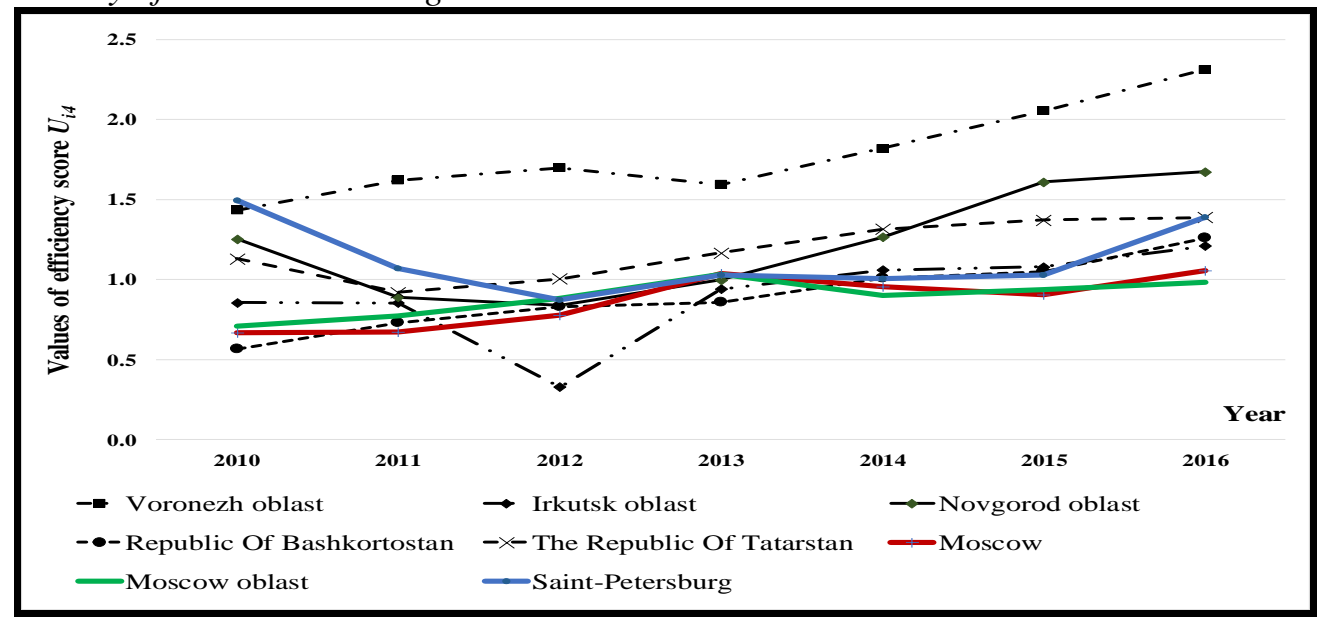

Figure 7 shows the dynamics of the total number of agent-enterprises and agentinvestors forecast with the help of the developed model (1)-(14) for the leading Russian regions (i.e., regions possessing the most number of such agents) for the period 2019 - 2022, in particular, Moscow, Moscow Oblast and St. Petersburg.

Figure 7. The dynamics of the total number of agent-enterprises and agent-investors forecast for the leading Russian regions

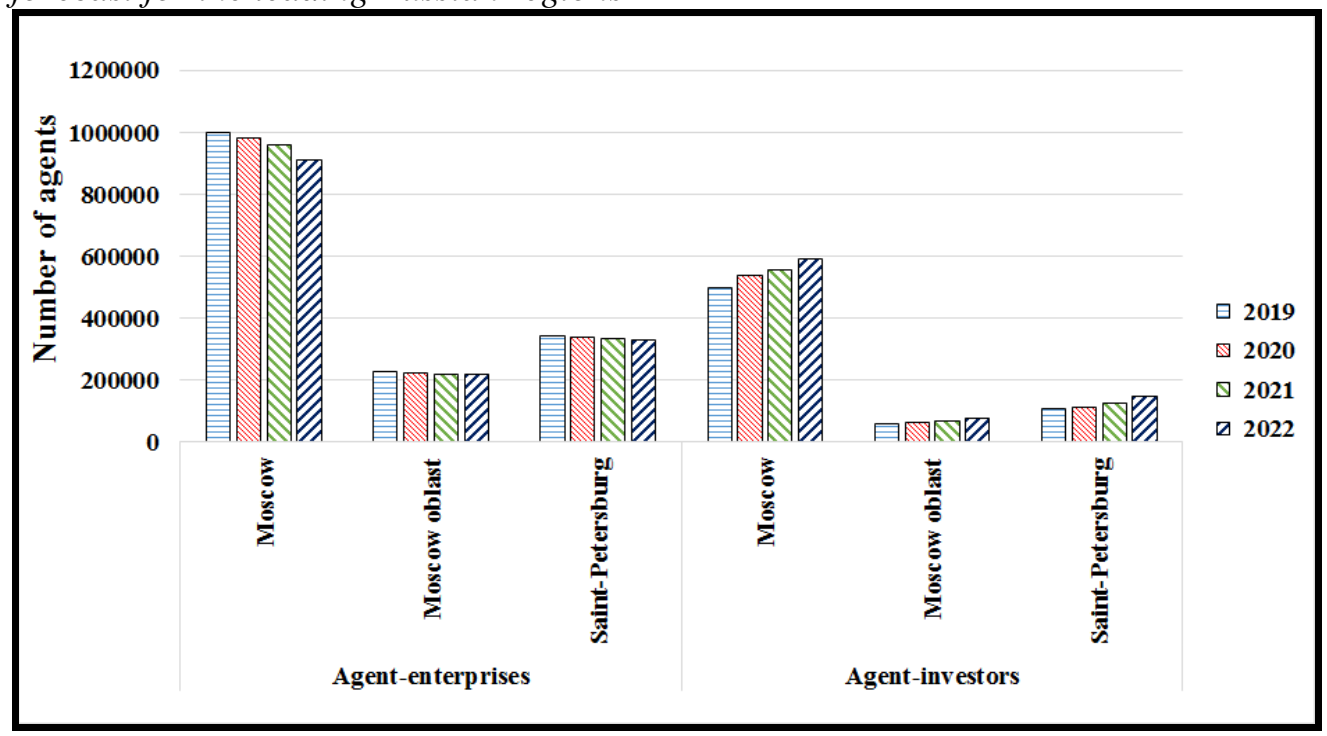


As shown in Figure 7, the total number of agent-enterprises in the leading regions for the considered period decreases as expected while the total number of agentinvestors demonstrates slow growth. Such dynamics are caused by increasing difficulties and barriers for Russian companies, especially for small enterprises (e.g., growing tax burden, lack of investment capital, oligopoly in Russian economy). At the same, time, the growth of the total number of agent-investors is caused by the greater attraction of assets in the leading regions in comparison with other territories.

\section{Discussion}

This study is based on modelling the efficiency of using production and investment resources at the regional level (1)-(14). The important feature of this approach is that it takes into account the average (normative) return of sectoral resources by computing of the efficiency scores of regions (10)-(11). It allows the strong heterogeneity of regional economies to be overcome (Beraja et al., 2019).

The important advantage of the suggested approach is that it provides an objective comparative assessment of the performance of using labour resources and fixed assets for the production and investment activity by all regions based on the dynamics of efficiency scores (Figures $3-6$ ). It allows clustering regions according to the level of their efficiency within the four main tasks, namely the 'Ratio of production to labour', 'Ratio of production to assets', 'Ratio of investments to labour' and 'Ratio of investments to assets' (Table 1 and Table 2).

At the same time, applying methods of agent-based modelling (Akopov et al., 2019; Akopov et al., 2017; Baindur and Viegas, 2011) allows the possibilities of the analysis of the production and investment characteristics of Russian regions to be extended, in particular, to forecast the total number of enterprises and investors at the regional level (Figure 7). The agent model developed in this work can be employed to develop a decision-making system for rational management at the regional level (Akopov and Beklaryan, 2014; Beklaryan, 2018).

A limitation of the model is that it ignores other important characteristics of the regional economy, in particular, the availability of social infrastructure facilities (schools, hospitals, etc.), per capita income, inflation, transport development and several other performance indicators. Thus, this article focuses only on regional production and investment activities. Nevertheless, the method can be extended to other areas of the regional economy through including appropriate metrics.

\section{Conclusion}

In conclusion, it should be noted that Russian regions need a more balanced economic policy that aims to remove significant disproportions in sizes and development levels of labour resources and fixed assets at the regional level. At the present time, we observe outflows of economic agents (humans, enterprises, 
investors, etc.) from regions with weak economies to leading regions (Moscow and Moscow Oblast). This is due to the 'gravity effect' described in this article (Figure 1). Agent-enterprises and agent-investors relocate to regions with more attractive production and investment characteristics. It is possible to change the preferences of economic agents through rational management at the regional level targeting predominantly the development of remote regions instead of leading regions (Moscow, Moscow Oblast and Saint Petersburg). Moreover, many Russian regions are more efficient at using resources for production and investment activity than these leading regions (Figures $3-5$ ).

The developed method and simulation model (Figure 2) can have a practical application for other countries with non-homogeneous regional economies. Moreover, it can be extended to other areas.

\section{References:}

Akopov, A.S., Beklaryan, L.A., Saghatelyan, A.K. 2019. Agent-based modelling of interactions between air pollutants and greenery using a case study of Yerevan, Armenia. Environmental Modelling and Software, 116, 7-25.

Akopov, A.S., Beklaryan, L.A., Saghatelyan, A.K. 2017. Agent-based modelling for ecological economics: A case study of the Republic of Armenia. Ecological Modelling, 346, 99-118.

Akopov, A.S., Beklaryan, L.A. 2015. An Agent Model of Crowd Behavior in Emergencies. Automation and Remote Control, 10, 1817-1827.

Akopov, A.S., Beklaryan, G.L. 2014. Modelling the dynamics of the 'Smarter Region'. In Proceedings of 2014 IEEE Conference on Computational Intelligence for Financial Engineering \& Economics, IEEE, 203-209.

Akopov, A.S., Hevencev, M.A. 2013. A multi-agent genetic algorithm for multi-objective Optimization. Proceedings of 2013 IEEE International Conference on Systems, Man, and Cybernetics, SMC 2013, 1391-1395.

Anderson, J.E. 1979. A Theoretical Foundation for the Gravity Equation. American Economic Review, Vol. 69, 106-116.

Baindur, D., Viegas, J.M. 2011. An agent based model concept for assessing modal share in inter-regional freight transport markets. Journal of Transport Geography, 19(6), 1093-1105.

Beklaryan, G.L. 2018. Decision support system for sustainable economic development of the Far Eastern Federal District. Business Informatics, 1(43), 66-75.

Beraja, M., Fuster, A., Hurst, E., Vavra, J. 2019. Regional Heterogeneity and the Refinancing Channel of Monetary Policy. The Quarterly Journal of Economics, 134(1), 109-183.

Berezhnaya, O.V., Berezhnaya, E.V. Chikaeva, K.S., Polivina, M.A., Berezhnoy, V.I. 2018. Opportunities for Assessing the Implementation of the Strategies for the Development of Russia's Macroregions. European Research Studies Journal, 21(2), 551-563.

Berger, T. 2001. Agent-based spatial models applied to agriculture: A simulation tool for technology diffusion, resource use changes and policy analysis. Agricultural Economics, 25(2-3), 245-260.

Borshchev, A. 2013. The Big Book of Simulation Modeling. Multimethod Modeling with AnyLogic 6. AnyLogic North America. 
Epstein, J.M. 2012. Generative social science: Studies in agent-based computational modeling. Princeton University Press.

Farmer, J.D., Foley, D. 2009. The economy needs agent-based modelling. Nature, 460 (7256), 685-686.

Forrester, J.W. 1958. Industrial Dynamics: A Major Breakthrough for Decision Makers. Harvard Business Review, 36(4), 37-66.

Miloradov, K.A., Romanishina, T.S., Kovalenko, A.A., Bondarenko, N.G., Andrianova, J.V. 2018. An Efficient Strategy for the Development of Tourism at Regional Level. European Research Studies Journal, 21(4), 208-221.

Parker, D.C., Manson, S.M., Janssen, M.A., Hoffmann, M.J., Deadman, P. 2003. Multi-agent systems for the simulation of land-use and land-cover change: A review Annals of the Association of American Geographers, 93(2), 314-337.

Partridge, M.D., Rickman, D.S. 1998. Regional Computable General Equilibrium Modeling: A Survey and Critical Appraisal. International Regional Science Review, 21(3), 205-248.

Porter, M.E. 2003. The economic performance of regions. Regional Studies, 37(6-7), 549578.

Ramos, R., Suriñach, J. 2013. A Gravity Model of Migration between ENC and EU. IZA Discussion, Paper No. 7700.

Schelling, T.C. 1971. Dynamic Models of Segregation. Journal of Mathematical Sociology, 1(2), 143-186.

Simmie, J., Martin, R. 2010. The economic resilience of regions: Towards an evolutionary approach. Cambridge Journal of Regions, Economy and Society, 3(1), 27-43.

Scott, A.J., Storper, M. 2003. Regions, globalization, development. Regional Studies, 37(67), 579-593.

Storper, M. 1997. The regional world: territorial development in a global economy. Guilford Press, London, $338 \mathrm{p}$.

Tesfatsion, L. 2002. Agent-based computational economics: growing economies from the bottom up. Artificial life, 8(1), 55-82.

Tinbergen, J. 1962. Shaping the World Economy: Suggestions for an International Economic Policy. New York, Twentieth Century Fund.

Torrens, P.M. 2001. Agent-based Models and the Spatial Sciences. Geography Compass, 4(5), 428-448.

Veselovsky, M.Y., Abrashkin, M.S., Vakhrushev, D.S., Parfenova, L.B., Volkov, A.Y. 2017. Knowledge-Based Engineering as a Driver of Economic Development of the Regions of Russia. European Research Studies Journal, (20)2B, 66-85.

Voronkova, O.Y., Zadimidcenko, A.M., Goloshchapova, L.V., Polyakova, A.G., Kamolov, S.G., Akhmetshin, E.M. 2018. Economic and Mathematical Modeling of Regional Industrial Processes. European Research Studies Journal, 21(4), 268-272.

Zelinskaya, A.B., Bogomolova, L.L., Kushnikov E.I. 2018. Problems of Innovative Development of the Northern Territories of Russia. European Research Studies Journal, 21(4), 600-610.

Zinovyeva, I.S., Kolesnichenko, E.A., Yakovlev, A.V. 2016. Zoning of Territory on the Basis of Modeling of Efficiency of Forest Resources Use in Russian Regions' Economy. European Research Studies Journal, 19(2), 239-250. 